\title{
Seroprevalence of Hepatitis E Virus in Iran: A Systematic Review and Meta-analysis
}

Meysam Behzadifar ${ }^{1}$, Kamran B Lankarani², Shadi Abdi ${ }^{3}$, Masood Taheri Mirghaed ${ }^{4}$, Gholam Beyranvand ${ }^{5}$, Abouzar Keshavarzi ${ }^{6}$, Gholamreza Ghoreishinia ${ }^{7}$, Aziz Rezapour ${ }^{4}$, Masoud Behzadifar ${ }^{4 *}$

1. Department of Epidemiology, Faculty of Health and Nutrition, Lorestan University of Medical Sciences, Khorramabad, Iran

2. Health Policy Research Center, Shiraz University of Medical Sciences, Shiraz, Iran

3. Department of Public Health, Faculty of Health and Nutrition, Student Research Committee, Lorestan University of Medical Sciences, Khorramabad, Iran

4. Health Management and Economics Research Center, Iran University of Medical Sciences, Tehran, Iran

5. Lorestan University of Medical Sciences, Khorramabad, Iran

6. Department of Health Education and Health Promotion, Faculty of Health, Shahid Sadoughi University of Medical Sciences, Yazd, Iran

7. Department of Operating Room, Faculty of Paramedicine, Zahedan University of Medical Sciences, Zahedan, Iran

\section{* Corresponding Author:}

Masoud Behzadifar, PhD Student Health Management and Economics Research Center, Iran University of Medical Sciences, Tehran, Iran

Telefax: + 982166123744

Email: masoudbehzadifar@gmail.com

Received: 08 Feb. 2016

Accepted: 21 May 2016

\section{ABSTRACT}

\section{BACKGROUND}

Hepatitis E virus (HEV) is one of common causes of viral hepatitis worldwide with higher prevalence in tropical and subtropical regions. Although epidemics of HEV have been reported from Iran, there are variable reports of this infection out of epidemics from different parts of Iran. This study aimed to determine the seroprevalence of HEV in Iran.

\section{METHODS}

In this systematic review and meta-analysis we searched PubMed, Scopus, Science direct, Google Scholar, Scientific Information Databank (SID), IranMedex, and Magiran for all relevant studies published in either English or Persian languages, up to 2015. Pooled seroprevalence estimates with a DerSimonian-Laird random-effects model were calculated. Statistical heterogeneity among the included studies was evaluated by Cochrane Q statistic and I 2 .

\section{RESULTS}

38 studies fulfilled the inclusion criteria compromising 18461 participants. The pooled seroprevalence rate of HEV in Iran was estimated about $10 \%(95 \% \mathrm{CI}=0.09$ 0.12 ) with maximum and minimum of $46 \%(95 \% \mathrm{CI}=0.42-0.50)$, and $0.01 \%(95 \%$ $\mathrm{CI}=0.000-0.002$ ), respectively.

\section{CONCLUSION}

HEV is common in Iran although the prevalence is lower than some neighbor countries.

\section{KEYWORDS}

Hepatitis E Virus; Seroprevalence; Meta-analysis; Systematic review; Iran

Please cite this paper as:

Behzadifar M, Lankarani KB, Taheri Mirghaed M, Abdi S, Beyranvand G, Keshavarzi A, Ghoreishinia GR, Rezapour A, Behzadifar M. Seroprevalence of Hepatitis E Virus in Iran: A Systematic Review and Meta-analysis. Middle East J Did Dis 2016;8:189-200. DOI : 10.15171/mejdd.2016.31

\section{INTRODUCTION}

Hepatitis E virus (HEV) is a common cause of community acquired viral hepatitis. ${ }^{1}$ The infection is endemic in many developing countries ${ }^{2}$ with a prevalence of as high as $50 \% .^{3}$ In non-endemic countries, the prevalence varies between $1 \%$ to $20 \%{ }^{4}$ This virus like hepatitis A does not lead to chronic hepatitis or carrier state in immunocompetent hosts. A special feature of HEV is its high mortality among pregnant women, which may reach up to $20-25 \%$ 
of cases. ${ }^{5}$ The infection could also become chronic in immunocompromised hosts specially recipients of solid organ transplantation. ${ }^{6}$

$\mathrm{HEV}$ has been reported worldwide, but it is more common in Central and South-West Asia. ${ }^{5}$ At least two epidemics of HEV have been reported from Iran in 1990 in Kermanshah province in western border of the country and in 1992 in Chahar Mahal and Bakhtiari province in central Iran. ${ }^{7}$

Out of these epidemics there are different reports of HEV prevalence in Iran. ${ }^{8}$ As HEV could cause both acute hepatitis in general population, and chronic disease in immunocompromised hosts, it is of utmost importance to have an estimate of this infection in the whole nation. This is not only of importance for Iran but could also help to better understand the epidemiology of this infection in other transitional societies. This study aimed to determine the seroprevalence of HEV in Iran in a systematic review and meta-analysis.

\section{MATERIALS AND METHODS}

\section{Databases:}

We performed a literature search on PubMed, Scopus, Science direct, Google Scholar, Scientific Information Databank (SID), IranMedex, and Magiran till March 2015 for HEV. Studies published in either English or Persian languages were included in the systematic review. The references of all selected published articles from the above databases were also searched to find more relevant studies. The abstract book of national and international conferences with the topic of liver disease, hepatology, hepatitis, and infectious diseases were also searched for HEV.

\section{Search strategy:}

Search strategy was based both on Medical Education Subject Headings (Mesh) terms as well as free text words and words in the title or abstract of studies. We used the following search strategy "HEV" OR "Hepatitis E Virus" AND "seroepidemiology" OR "Epidemiology” OR "Prevalence” AND "Iran”, in Persian or English languages.

\section{Study Selection:}

The inclusion criteria were: studies that had data indicating the seroprevalence of HEV using standard meth- ods. The exclusion criteria were: studies that did not clearly separate the prevalence of HEV form other viral diseases, studies with unknown sample origins, studies with overlapping time, subjects and place of sample collection, case reports and case series, studies focusing on treatment, studies reporting on HEV among patients with non-Iranian nationality.

\section{Data Extraction:}

Two investigators (Masoud.Behzadifar and Meysam. Behzadifar) independently applied inclusion criteria and selected studies and extracted the data. Data from the included studies, including the name of the first author, year of publication, location of study, age, sex, type of study, sample size, and number of the infected cases and conflicts were recorded for further analysis.

\section{Assessment of studies:}

STROBE questionnaire was used ${ }^{9}$ to assess the quality of the studies. All studies were scored by two investigators (Gholamreza.Ghoreishinia, Abouzar.Keshavarzi) separately and mean score was calculated for each study. The studies with score less than 7.5 were considered as poor quality. For 38 articles in this review, the obtained score was 18.11 .

\section{Statistical Analysis:}

In studies where the SE (standard error) was not reported we calculated it from the prevalence using the following formula:

$\mathrm{SE}=\sqrt{(\mathrm{P}(1-\mathrm{P}) / \mathrm{N})} \quad(\mathrm{P}=$ prevalence, $\mathrm{N}=$ sample size $)$

Confidence interval (CI) $95 \%=\mathrm{P} \pm 1.96 \times \mathrm{SE}$

Studies were estimated with respect to the prevalence with $\mathrm{CI}$ and $\mathrm{P}$ value. Statistical heterogeneity among the included studies were measured by Cochrane Q statistic and I2.10 Rank of I2 was predefined as a Cochrane Q of $25 \%=$ low heterogeneity, $50 \%=$ medium heterogeneity, and $75 \%=$ high heterogeneity, respectively. $\mathrm{P}<0.05$ was considered as statistically significant. We considered studies reporting HEV in Iran using random effects model. Metaregression analysis of the variables of each study such as sample size, and the year of publication, sex, type of study, and the subgroup analyses were done when possible. Publication bias was assessed by Egger's ${ }^{11}$ and Begg's ${ }^{12}$ tests and graphically depicted by a funnel plot. All data analy- 

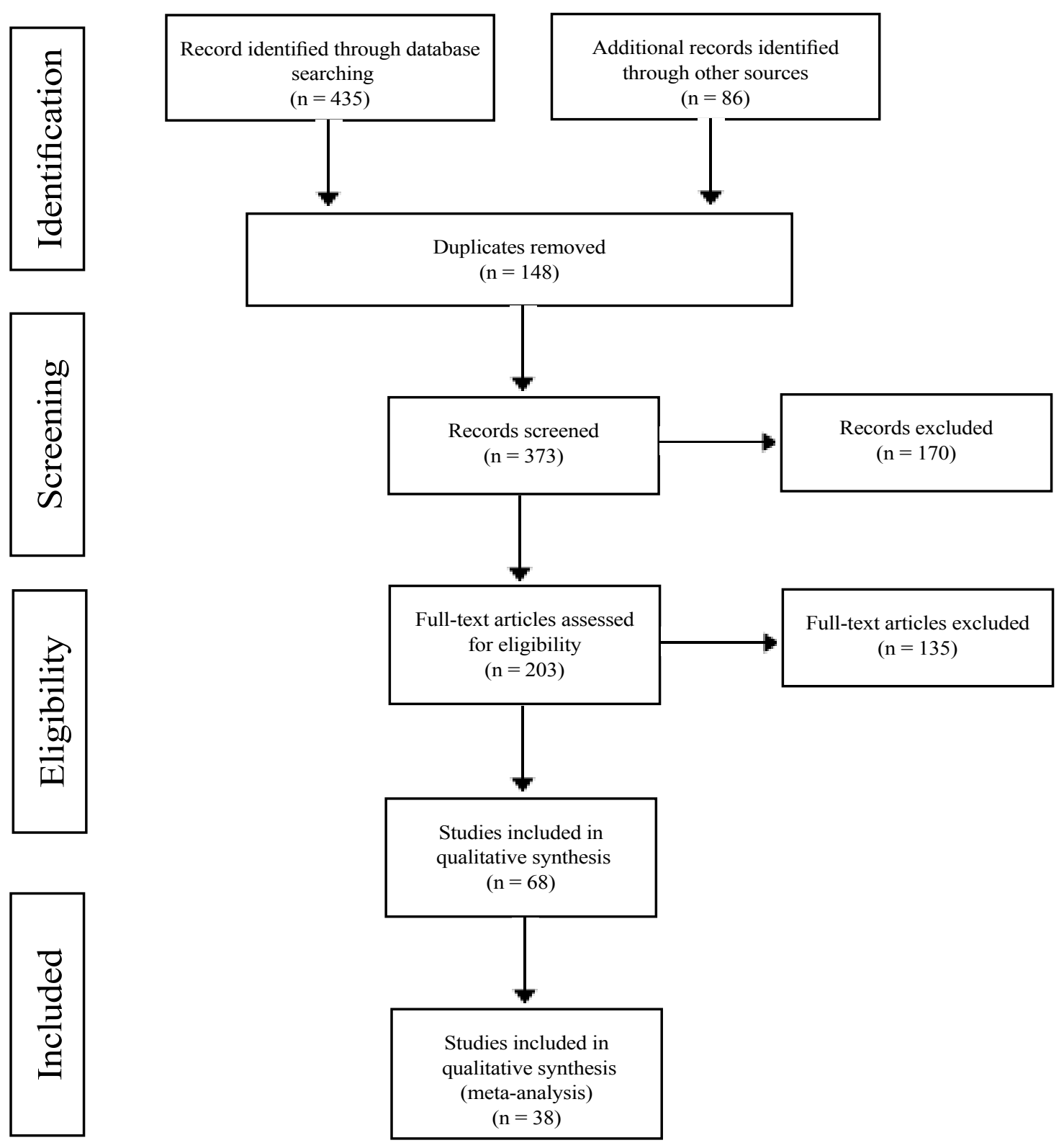

Fig.1: Flowchart of search and studies selection

ses were conducted with STATA software Version 11.0 (Stata Crop LP, College Station, Texas, USA).

\section{RESULTS}

Based on our search strategy described above 521 articles were initially retrieved. Of them, 148 articles were excluded as duplicate publications. We carefully read the titles and abstracts of the remaining 373 articles and further 170 records were excluded based on the exclusion criteria mentioned above. After reading the full text of the remaining 203 articles, an additional 135 articles were further found to have one of the exclusion criteria. Finally, 38 studies ${ }^{13-50}$ were found eligible for final analysis and were used for this meta-analysis. This systematic review and meta-analysis is reported according to the preferred reporting items for systematic reviews and meta-analyses (PRISMA) guidelines 51 are shown in figure 1 .

Included studies consisted of cross sectional and case control designs. The characteristics of all studies are 
Table 1: Characteristics of included studies in the meta-analysis

\begin{tabular}{|c|c|c|c|c|c|c|c|}
\hline Author & Year & Sample & Location & Sample population & Sex & Type of study & Age \\
\hline Eini & 2015 & 153 & Hamedan & $\begin{array}{l}\text { Hemodialysis } \\
\text { patients }\end{array}$ & $\mathrm{M} / \mathrm{F}$ & $\mathrm{Cr}-\mathrm{Sec}$ & $>40-<60$ \\
\hline Beladi Mousavi & 2014 & 47 & Ahvaz & $\begin{array}{l}\text { Hemodialysis } \\
\text { patients }\end{array}$ & $\mathrm{M} / \mathrm{F}$ & $\mathrm{Cr}-\mathrm{Sec}$ & $55.27 \pm 8.1$ \\
\hline Rostamzadeh & 2013 & 136 & Urmia & Pregnant Women & $\mathrm{F}$ & $\mathrm{Cr}-\mathrm{Sec}$ & $25.12 \pm 4.91$ \\
\hline Ahmadi & 2013 & 1582 & Mashhad & General population & $\mathrm{M} / \mathrm{F}$ & $\mathrm{Cr}-\mathrm{Sec}$ & $29.06 \pm 18.513$ \\
\hline Ehteram & 2013 & 530 & Arak & Blood donors & $\mathrm{M} / \mathrm{F}$ & $\mathrm{Cr}-\mathrm{Sec}$ & $18-50$ \\
\hline Zekavat & 2013 & 356 & Jahrom-Shiraz & $\begin{array}{l}\text { Hemodialysis } \\
\text { patients }\end{array}$ & $\mathrm{M} / \mathrm{F}$ & $\mathrm{Cr}-\mathrm{Sec}$ & $24-80$ \\
\hline Rostamzadeh & 2011 & 91 & Urmia & $\begin{array}{l}\text { Renal Transplant } \\
\text { Recipients }\end{array}$ & $\mathrm{M} / \mathrm{F}$ & $\mathrm{Cr}-\mathrm{Sec}$ & $35.4 \pm 14.5$ \\
\hline Sepanlou & 2010 & 1423 & Tehran-Golestan & General population & $\mathrm{M} / \mathrm{F}$ & $\mathrm{Cr}-\mathrm{Sec}$ & $37.9 \pm 13.4$ \\
\hline Mobaien & 2013 & 93 & Zanjan & $\begin{array}{l}\text { Hemodialysis } \\
\text { patients }\end{array}$ & $\mathrm{M} / \mathrm{F}$ & $\mathrm{Cr}-\mathrm{Sec}$ & $57.0 \pm 18.5$ \\
\hline Saffar & 2009 & 1102 & Sari & General population & $\mathrm{M} / \mathrm{F}$ & $\mathrm{Cr}-\mathrm{Sec}$ & $2-25$ \\
\hline Taremi & 2008 & 1824 & Nahavand & General population & $\mathrm{M} / \mathrm{F}$ & $\mathrm{Cr}-\mathrm{Sec}$ & $34.7 \pm 19.5$ \\
\hline Ataei & 2009 & 816 & Isfahan & General population & $\mathrm{M} / \mathrm{F}$ & $\mathrm{Cr}-\mathrm{Sec}$ & $6->50$ \\
\hline Assarehzadegan & 2008 & 400 & Khuzestan & Blood donors & $\mathrm{M} / \mathrm{F}$ & $\mathrm{Cr}-\mathrm{Sec}$ & $18-60$ \\
\hline Taremi & 2007 & 399 & Tabriz & Blood donors & $\mathrm{F}$ & $\mathrm{Cr}-\mathrm{Sec}$ & $31.4 \pm 9.8$ \\
\hline Taremi & 2005 & 324 & Tabriz & $\begin{array}{l}\text { Hemodialysis } \\
\text { patients }\end{array}$ & $\mathrm{M} / \mathrm{F}$ & $\mathrm{Cr}-\mathrm{Sec}$ & $53.5 \pm 15.1$ \\
\hline Ramezani & 2013 & 152 & Tehran & Patients HIV & $\mathrm{M} / \mathrm{F}$ & $\mathrm{Cr}-\mathrm{Sec}$ & $38.73 \pm 0.78$ \\
\hline Mohebbi & 2012 & 551 & Tehran & General population & $\mathrm{M} / \mathrm{F}$ & $\mathrm{Cr}-\mathrm{Sec}$ & $41.28 \pm 16.96$ \\
\hline Nazer & 2012 & 400 & Khorramabad & General population & $\mathrm{M} / \mathrm{F}$ & $\mathrm{Cr}-\mathrm{Sec}$ & 36 \\
\hline Tahamtan & 2013 & 150 & Gorgan & $\begin{array}{l}\text { Hemodialysis } \\
\text { patients }\end{array}$ & $\mathrm{M} / \mathrm{F}$ & $\mathrm{Cr}-\mathrm{Sec}$ & $>30-<70$ \\
\hline Ghadir & 2007 & 697 & Golestan & General population & $\mathrm{M} / \mathrm{F}$ & $\mathrm{Cr}-\mathrm{Sec}$ & $43 \pm 15.1$ \\
\hline Moradi & 2010 & 1200 & Gorgan & Pregnant Women & $\mathrm{F}$ & $\mathrm{Cr}-\mathrm{Sec}$ & $27 \pm 6.3$ \\
\hline khoshbaten & 2001 & 324 & Tabriz & $\begin{array}{l}\text { Hemodialysis } \\
\text { patients }\end{array}$ & $\mathrm{M} / \mathrm{F}$ & $\mathrm{Cr}-\mathrm{Sec}$ & $53 \pm 15.11$ \\
\hline Gachkar & 2005 & 399 & Tabriz & Blood donors & $\mathrm{F}$ & $\mathrm{Cr}-\mathrm{Sec}$ & $40.7 \pm 12.4$ \\
\hline shavakhi & 2007 & 200 & Tehran & liver cirrhosis & $\mathrm{M} / \mathrm{F}$ & $\mathrm{Ca}-\mathrm{Con}$ & $\mathrm{ca}=43 \pm 14.6, \mathrm{cl}=44.9 \pm 17.5$ \\
\hline Eslamifar & 2012 & 184 & Tehran & Patients HIV & $\mathrm{M} / \mathrm{F}$ & Ca-Con & $38.82 \pm 0.8$ \\
\hline Rezazadeh & 2006 & 280 & Hamedan & Blood donors & $\mathrm{M} / \mathrm{F}$ & $\mathrm{Cr}-\mathrm{Sec}$ & $>40-<40$ \\
\hline Alavi & 2007 & 228 & Ahvaz & Drug addiction & $\mathrm{F}$ & $\mathrm{Cr}-\mathrm{Sec}$ & $\mathrm{ca}=33.24 \pm 7.59, \mathrm{cl}=31.2 \pm 7.59$ \\
\hline Sharif & 2013 & 558 & Kashan & Children & $\mathrm{M} / \mathrm{F}$ & $\mathrm{Cr}-\mathrm{Sec}$ & 1 to 15 \\
\hline Noroozi & 2012 & 740 & Qom & General population & $\mathrm{M} / \mathrm{F}$ & $\mathrm{Cr}-\mathrm{Sec}$ & $>15$ \\
\hline Mohebbi & 2012 & 493 & Tehran & General population & $\mathrm{M} / \mathrm{F}$ & $\mathrm{Cr}-\mathrm{Sec}$ & $40.98 \pm 17.10$ \\
\hline Ghorbani & 2007 & 800 & Tehran & Military & $\mathrm{M}$ & $\mathrm{Cr}-\mathrm{Sec}$ & $19 \pm 1$ \\
\hline Somi & 2007 & 200 & Azerbaijan & Blood donors & $\mathrm{M} / \mathrm{F}$ & $\mathrm{Cr}-\mathrm{Sec}$ & $48.26 \pm 18.19$ \\
\hline Pourahmad & 2009 & 43 & Jahrom & $\begin{array}{l}\text { Hemodialysis } \\
\text { patients }\end{array}$ & $\mathrm{M} / \mathrm{F}$ & $\mathrm{Cr}-\mathrm{Sec}$ & $59.3 \pm 14.4$ \\
\hline Shamsizadeh & 2009 & 566 & Ahvaz & Children & $\mathrm{M} / \mathrm{F}$ & $\mathrm{Cr}-\mathrm{Sec}$ & 6 to 15 \\
\hline Aminiafshar & 2004 & 90 & Tehran & Blood donors & $\mathrm{M} / \mathrm{F}$ & $\mathrm{Cr}-\mathrm{Sec}$ & $31.8 \pm 11$ \\
\hline Keramat & 2014 & 262 & Hamedan & Drug addiction & $\mathrm{M} / \mathrm{F}$ & $\mathrm{Cr}-\mathrm{Sec}$ & $\begin{array}{c}\text { IDUs }=35.57 \pm 8.13, \text { non } \\
\text { IDUs }=31.57 \pm 8.19\end{array}$ \\
\hline Joulaei & 2015 & 158 & Shiraz & Patients with HIV & $\mathrm{M} / \mathrm{F}$ & $\mathrm{Cr}-\mathrm{Sec}$ & $39.1 \pm 8$ \\
\hline Farshadpour & 2015 & 510 & Ahvaz & community-based & $\mathrm{M} / \mathrm{F}$ & $\mathrm{Cr}-\mathrm{Sec}$ & $45.89 \pm 14.63$ \\
\hline
\end{tabular}

M/F: Male - Female, Cr-Sec: Cross - Sectional, Ca-Con: Case-Control, IDUs= Injection Drug Users 


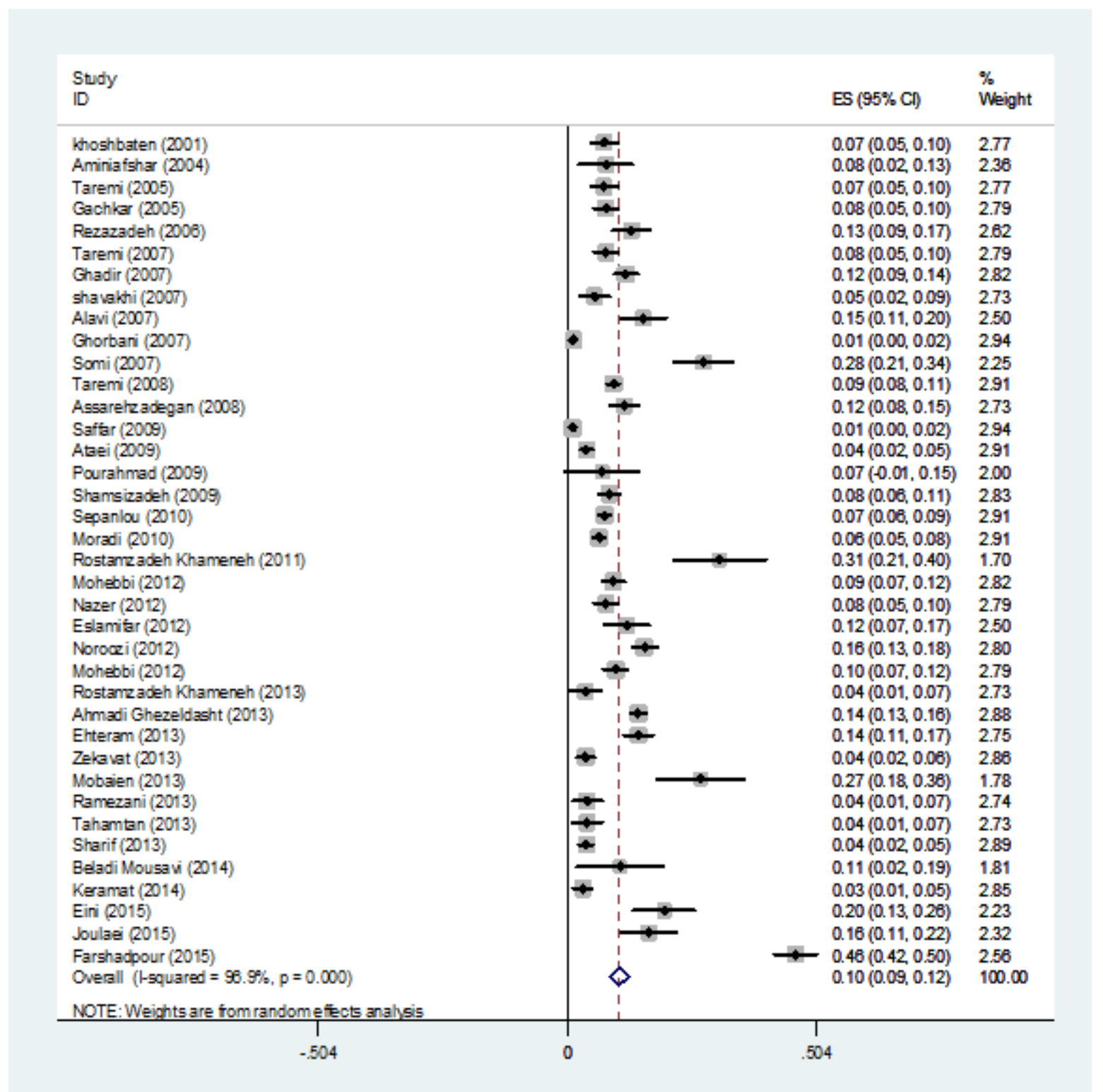

Fig.2: Forest plots of seroprevalence rate of hepatitis $\mathbf{E}$ virus infection in Iran and $95 \%$ confidence interval

demonstrated in table1.

The total sample size included 18,461 participants from 38 studies. The result of Q Cochran test (chi squared $=1194.08$, D.F $=37, p=0.000$ and $\mathrm{I} 2=96.9 \%$.) indicated strong heterogeneity among the 38 studies. According to the random model analysis, the overall seroprevalence of HEV in Iran was estimated 10\% (95\% $\mathrm{CI}=0.09-0.12)$ with a maximum and minimum value of $46 \%(95 \% \mathrm{CI}=0.42-0.50)$, and $0.01 \%(95 \% \mathrm{CI}=0.000$ 0.002 ), respectively (figure 2).

In all included studies, individuals were entered ran- domly. The maximum seroprevalence rate of $46 \%$ was reported by Farshadpour from Ahvaz (2015) in southwest border of Iran and Iraq. The minimum seroprevalence rate of $1 \%$ was reported by Ghorbani in Tehran and by Saffar in Yazd located in the central desert of Iran in 2010 and 2006, respectively. Seroprevalence rate in both sexes (female-male) was $11 \%(95 \% \mathrm{CI}=0.09$ $0.14)$, the seroprevalence rate in female patients was $8 \%$ ( $95 \% \mathrm{CI}=0.05-0.10)$, and the seroprevalence in male patients was $1 \%(95 \% \mathrm{CI}=0.00-0.02)$ (figure $3 \mathrm{~A})$. The seroprevalence rate was $11 \%(95 \% \mathrm{CI}=0.09-0.13)$ 


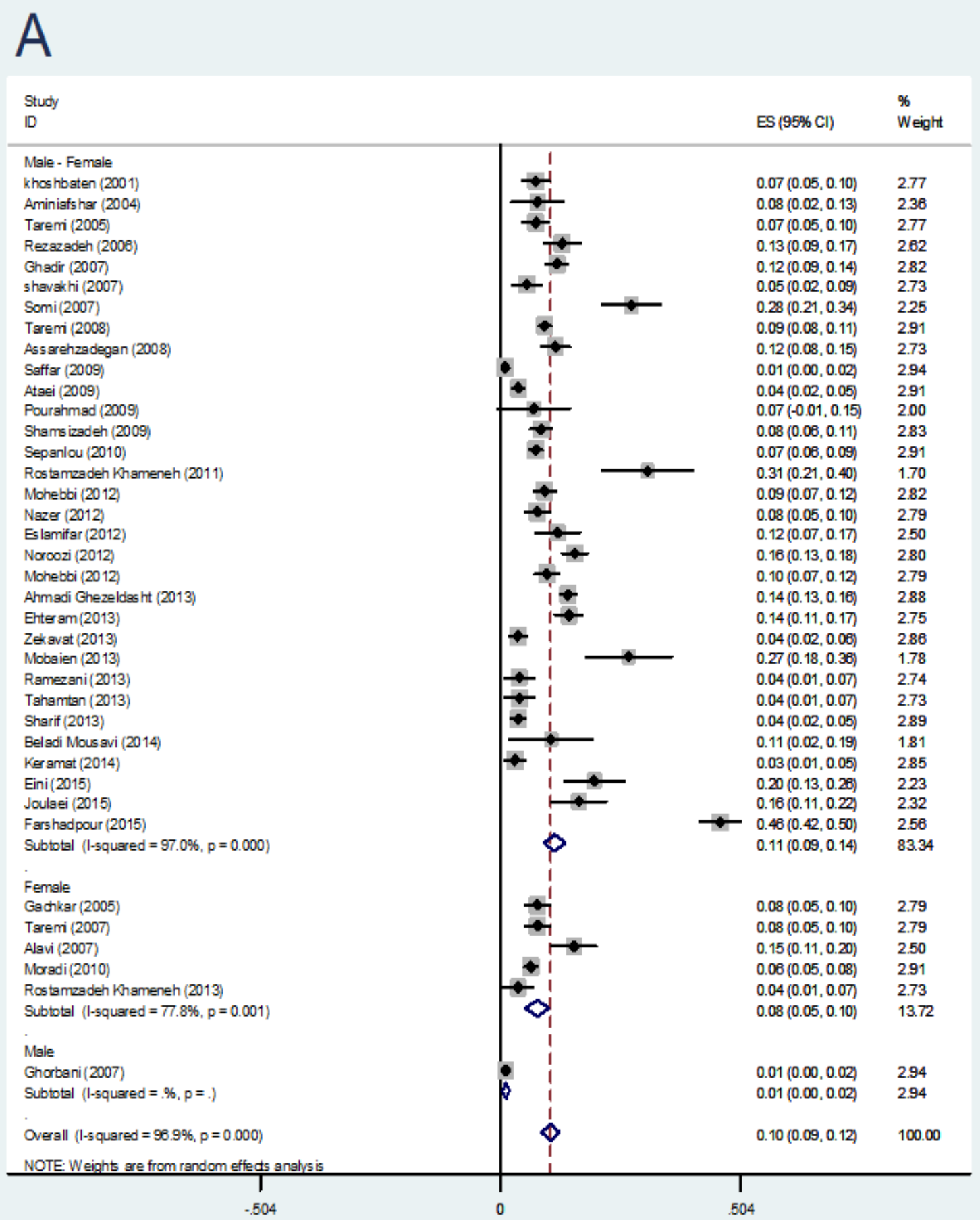

Fig. 3A : Forest plots of hepatitis $E$ virus prevalence in Iran by sex (A)

in cross sectional studies and $8 \%(95 \% \mathrm{CI}=0.02-0.15)$ in case control studies (figure 3B).

To assess publication bias by a funnel plot, we used
Begg's and Egger test. The results of Begg's was $p=0.068$ and Egger tests was $p=0.000$. This finding indicates a significant publication bias (figure 4). 


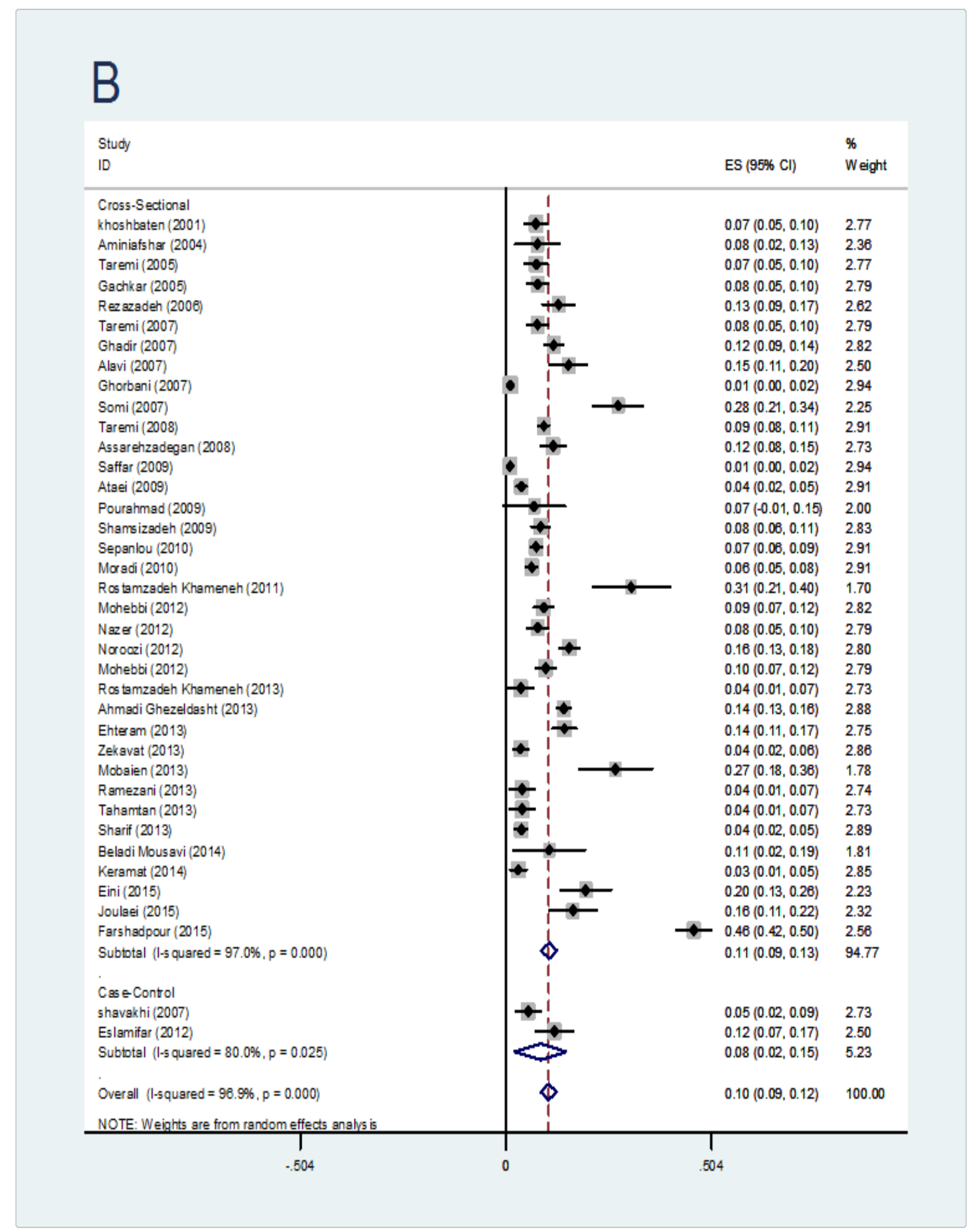

Fig. 3B : Forest plots of hepatitis $\mathbf{E}$ virus prevalence in Iran by study type (B) 
Table 2: Characteristics of study population and percentage in 38 studies included in meta-analysis of hepatitis $\mathbf{E}$ virus prevalence in Iran

\begin{tabular}{|c|c|c|c|c|c|}
\hline \multirow[t]{2}{*}{ Subgroups } & \multirow[t]{2}{*}{ No. of studies } & \multirow[t]{2}{*}{ Sample size } & \multirow{2}{*}{$\begin{array}{c}\text { Prevalence \% } \\
(95 \% \mathrm{CI})\end{array}$} & \multicolumn{2}{|c|}{ Heterogeneity } \\
\hline & & & & $\mathbf{I}^{2}$ & $p$ \\
\hline Blood donors & 7 & 2298 & $\begin{array}{c}12.3 \% \\
{[0.087 \text { to } 0.160]}\end{array}$ & $87.0 \%$ & 0.000 \\
\hline General population & 11 & 10138 & $\begin{array}{c}12.1 \\
{[0.078 \text { to } 0.164]}\end{array}$ & $98.8 \%$ & 0.000 \\
\hline Military & 1 & 800 & $\begin{array}{c}11 \% \\
{[0.004 \text { to } 0.019]}\end{array}$ & - & - \\
\hline Patients with HIV & 3 & 494 & $\begin{array}{c}10.5 \% \\
{[0.029 \text { to } 0.181]}\end{array}$ & $88.6 \%$ & 0.000 \\
\hline Hemodialysis patient & 8 & 1490 & $\begin{array}{c}9.5 \% \\
{[0.059 \text { to } 0.132]}\end{array}$ & $85.6 \%$ & 0.000 \\
\hline Drug addiction & 2 & 490 & $\begin{array}{c}9 \% \\
{[-0.030 \text { to } 0.211]}\end{array}$ & $95.5 \%$ & 0.000 \\
\hline Children & 2 & 1124 & $\begin{array}{c}6 \% \\
{[0.014 \text { to } 0.107]}\end{array}$ & $90.9 \%$ & 0.000 \\
\hline liver cirrhosis & 1 & 200 & $\begin{array}{c}5.5 \% \\
{[0.023 \text { to } 0.087]}\end{array}$ & - & - \\
\hline Pregnant women & 2 & 1336 & $\begin{array}{c}5.4 \% \\
{[0.029 \text { to } 0.079]}\end{array}$ & $56.1 \%$ & 0.131 \\
\hline Renal transplant recipients & 1 & 91 & $\begin{array}{c}3.8 \% \\
{[0.213 \text { to } 0.403]}\end{array}$ & - & \\
\hline
\end{tabular}

Seroprevalence of HEV decreased by reduced sample size and later publication year but it was not significant. In table 3 , a summary of data related to meta-regression is shown.

Table 3: Result of Meta- regression investigating the effect of sample size and year on seroprevalence of hepatitis $E$ virus in Iran

\begin{tabular}{lcccccc}
\hline & Coefficient & Standard error & T & $p$ & L CI & UCI \\
\hline Sample size & -.0000275 & .0000329 & -0.84 & 0.409 & -.0000942 & .0000392 \\
\hline Year & .005872 & .0041553 & 1.41 & 0.166 & -.0025636 & $\ldots 143076$ \\
\hline Cons & -11.68132 & 8.353102 & -1.40 & 0.171 & -28.63902 \\
\hline
\end{tabular}

LCI: Lower Confidence Interval UCI: Upper Confidence Interval Cons=Index is calculated in this study, SE (Standard Error)

\section{DISCUSSION}

Studies in different parts of the world show a wide variation in the seroprevalence of HEV. The present study estimated the overall seroprevalence of HEV in Iran as $10 \%$. There was a wide variation in HEV seroprevalence in the included studies in this meta-analysis. The highest report belonged to Ahvaz, the center of Khozestan province in our border with Iraq. The population in this region travel frequently to Iraq. There are several reports of endemicity of HEV in Iraq even in Baghdad, the capital. ${ }^{52,53}$ Interestingly although the general trend of the publications shows a lower prevalence in recent years, the situation is reverse in Khozestan and Ahvaz showing an increase in the prevalence from $11.5 \%$ in a study in
2008 to $46 \%$ in 2015 . This corresponds to a period of more mobility along Iran / Iraq border in recent years. The disposal of waste water in Ahvaz also has faced many challenges especially after the recent cycles of drought and flood in the province in contrast to the lowest prevalence reported from Tehran with much better sanitation. The other region with much lower prevalence is Yazd with its surrounding deserts and dry weather.

In our meta-analysis the prevalence of $\mathrm{HEV}$ among children and pregnant women was $6 \%$ and $5.4 \%$ respectively. This is probably because of higher exposure of people with advanced age but as we had limited data we could not confirm the effect of age on seroprevalence.

The prevalence of $\mathrm{HEV}$ was not different among 

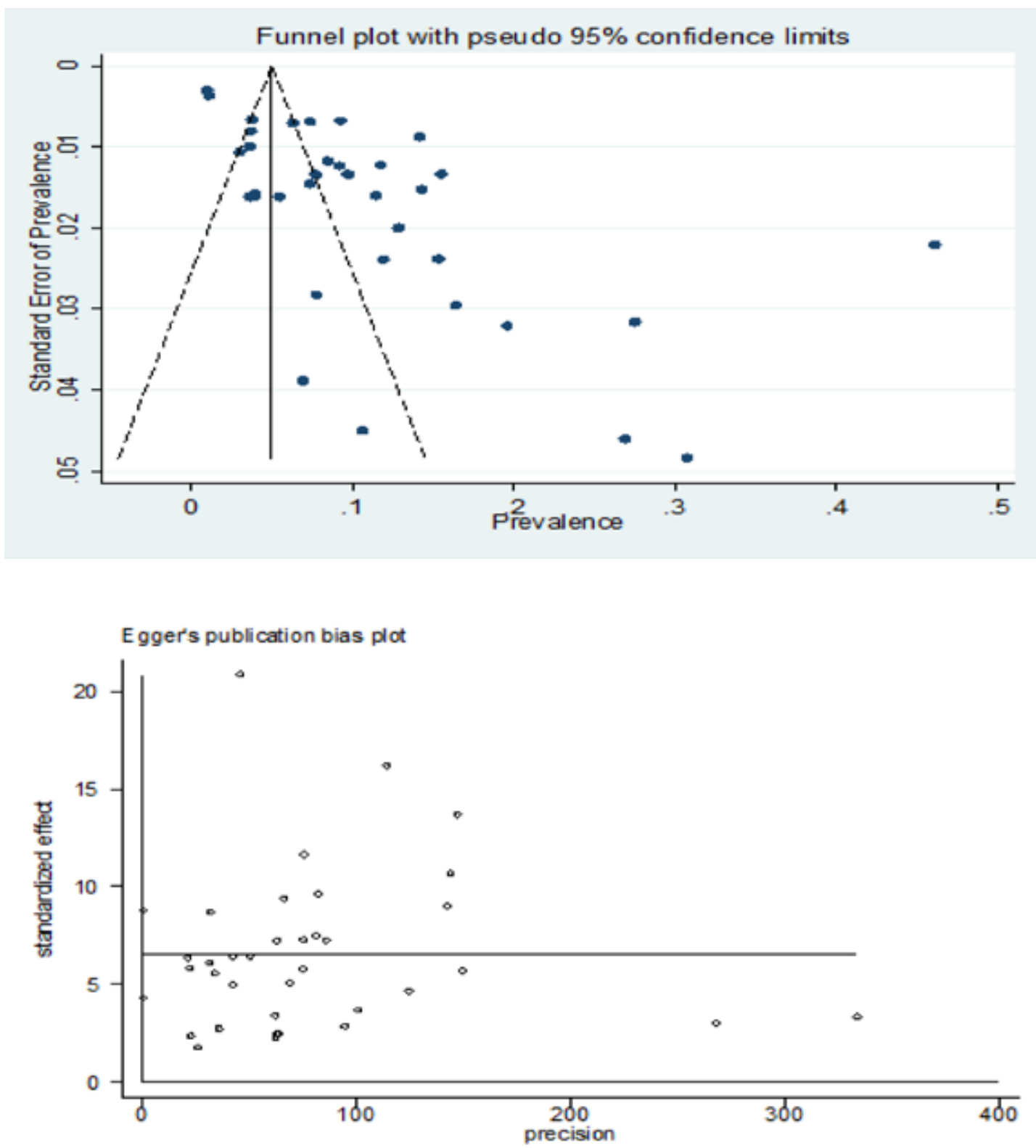

Fig. 4 : Funnel plot and Egger's funnel plot test to assess publication bias

patients receiving hemodialysis, intravenous drug users, and HIV infected patients compared to the general population. One should realize that the most common route of HIV infection in Iran is still intravenous drug use, although the trend is moving toward sexual route. ${ }^{54}$ This indicates that in concordance with other reports, the major route of transmission of $\mathrm{HEV}$ is fecal oral rather than parenteral.

It is of interest that in patients with cirrhosis the prevalence was $5.5 \%$ and in renal transplant recipients it was $3.8 \%$. As these reports were based on serology and these patients might have exposure to HEV with loss of antibody over time due to malnutrition or immunosuppression, our estimates in these special groups might be incorrect.

This systematic review and meta-analysis has advantage of a relatively large sample size with merging data of good quality studies but it also has several limitations. Although the included studies were from many parts of the country, there were some regions with no data. For 
instance we could not find any eligible study from two regions with confirmed epidemics of HEV in Iran naming Kermanshah and Chahar Mahal Bakhtiari provinces. The studies analyzed in this systematic review used several different types of serology for HEV from different sources, and their comparability is not known. There was a lack of appropriate data on the age and sex in some of the included studies. Consequently, we were not able to analyze the data by stratifying these variables. Using the information on sex and age, we could better estimate the prevalence of hepatitis E among subgroups in our society. Substantial heterogeneity of $95.7 \%$, according to the $\mathrm{I}^{2}$ statistic is another limitation. Of utmost importance is that none of the studies reported the prevalence of HEV among patients suffering from acute hepatitis. Despite these limitations, our study reveals that HEV in Iran is not rare and is not limited to epidemics.

HEV in Iran has an estimated prevalence of $10 \%$. The infection seems to have a decreasing trend overtime, which might be related to improved sanitation and better access to safe water but the pattern is not uniform across the entire country with existence of certain confounders such as mobility along borders especially to countries with high endemicity of HEV. Further prospective studies on incidence of infection, especially in patients suffering from acute hepatitis in non-epidemic conditions are required to obtain better knowledge on the dynamics of this virus in our country.

\section{Authors' contributions:}

All of the authors significantly contributed to this systematic review and meta-analysis. All made the search in databases. Masoud Behzadifar, Meysam Behzadifar, Abouzar Keshavarzi, and Maryam Saran reviewed the literature, selected and assessed the articles. Masoud Behzadifar analyzed the data. Kamran B Lankarani provided critical comments for the subsequent drafts. All of the authors reviewed the final manuscript and approved the final version.

\section{CONFLICT OF INTEREST}

The authors declare no conflict of interest related to this work.

\section{REFERENCES}

1. Purcell RH, Emerson SU. Hepatitis E: an emerging awareness of an old disease. J Hepatol 2008;48: 494-503. doi: 10.1016/j.jhep.2007.12.008.

2. Keane F, Gompels M, Bendall R, Drayton R, Jennings L, Black $\mathrm{J}$, et al. Hepatitis $\mathrm{E}$ virus coinfection in patients with HIV infection. HIV Med 2012;13:83-8. doi: 10.1111/ j.1468-1293.

3. Taniguchi M, Kim SR, Mishiro S, Takahashi K, Shin MH, Yun H, et al. Epidemiology of hepatitis E in Northeastern China, South Korea and Japan. J Infect 2009;58:232-7. doi: 10.1016/j.jinf.

4. Dalton HR, Bendall R, Ijaz S, Banks M. Hepatitis E: An emerging infection in developed countries. Lancet Infect Dis 2008;8:698-709. doi: 10.1016/S1473-3099(08)70255-X.

5. Vasickova P, Psikal I, Kralik P. Hepatitis E virus: a review. Vet Med 2007; 8: 365-84.

6. Behrendt P, Steinmann E, Manns MP, Wedemeyer H. The impact of hepatitis $\mathrm{E}$ in the liver transplant setting. J Hepatol 2014;61:1418-29. doi: 10.1016/j.jhep.2014.08.047.

7. Taremi M, Khoshbaten M, Gachkar L, EhsaniArdakani MJ, Zali M. Hepatitis E virus infection in hemodialysis patients: A seroepidemiological survey in Iran. BMC Infect Dis 2004;5:36-8. doi: 10.1186/1471-2334-5-36

8. Alizadeh AH, Taromi M, Ansari S, Ardalan A, Mahmood Araabi M, Zali MR. Prevalence of hepatitis E antibodies and cofactors in the population over 6 years old in Nahavand in 2003. Res J Shaheed Beheshti Univ Med Sci 2004 7: 489-94.

9. Von Elm E, Altman DG, Egger M, Pocock SJ, Gotzsche PC, Vandenbroucke JP. The strengthening the reporting of observational studies in epidemiology (STROBE) statement: guidelines for reporting observational studies. Ann Intern Med 2007;147:573-7. doi: 10.1371/journal. pmed.0040296

10. Higgins JP, Thompson SG, Deeks JJ, Altman DG. Measuring inconsistency in meta-analyses. $\mathrm{Br}$ Med $J$ 2003;327:557-60.

11. Egger M, Davey Smith G, Schneider M, Minder C. Bias in Meta-Analysis Detected by a Simple,Graphical Test. BMJ 1997;315:629-34. doi:10.1136/bmj.315.7109.629

12. Begg CB, Mazumdar M. Operating Characteristics of a Rank Correlation Test for Publication Bias. Biometrics 1994;50:1088-101. doi: 10.2307/2533446

13. Ahmadi-Ghezeldasht S, Miri R, Hedayati-moghadam M. Population Movement and Virus Spreading: HEV Spreading in a Pilgrimage City, Mashhad in Northeast Iran; an Example. Hepat Mon 2013;13: e10255. doi: 10.5812/ hepatmon.

14. Alavi SM, Ahmadi F, Ghasemirad M, Nikkhooi A. The correlation between Hepatitis E seropositiveness and intravenous drug using in the drug users who referred to the drug treatment centers in Ahvaz, 2005-2006. J Shahrekord 
Uuni Med Sci 2007;9:15-20.

15. Aminiafshar S, Alimagham M, Gachkar L, Yousefi Y, Attarchi Z. Anti Hepatitis E Virus Seropositivity in a Group of Blood Donors. Irani J Pub Health 2004;33:53-6.

16. Assarehzadegan MA, Shakerinejad G, Amini A, Rezaee AR. Seroprevalence of hepatitis E virus in blood donors in Khuzestan Province, Southwest Iran. Intern J Infec Dis 2008;12:387-90.

17. Ataei B, Nokhodian Z, Javadi AA, Kassaian N, Shoaei P, Farajzadegan Z, eT al. Hepatitis E virus in Isfahan Province: a population-based study. Intern J Infec Dis 2009;13:67-71. doi: 10.1016/j.ijid.2008.03.030.

18. Beladi Mousavi SS, Motemednia F, Beladi Mousavi M. Epidemiology of Hepatitis E Virus Infection in Patients on Chronic Hemodialysis. Jundi J Microbiol 2014;7:6993. doi: $10.5812 /$ jjm.6993.

19. Ehteram H, Ramezani A, Eslamifar A. Seroprevalence of Hepatitis E Virus infection among volunteer blood donors in central province of Iran in 2012. Iran J Microbiol 2013;5:172-6.

20. Eini P, Mamani M, Javani M. Seroprevalence of Hepatitis E Among Hemodialysis Patients: A Report From Hamadan, Iran. Hepat Mon 2015;15:e26260. doi: 10.5812/hepatmon.15(5)2015.26260. eCollection 2015.

21. Eslamifar A, Aghakhani A, Mohraz M, Banifazl M, Foroghi M, Ansari F, et al. Seroepidemiology hepatitis E in patients infected with human immunodeficiency virus. Iran J Infec Dis Trop Med 2012;17: 33-6.

22. Farshadpour F, Taherkhani R, Makvandi M. Prevalence of Hepatitis E Virus among Adults in SouthWest of Iran. Hepat Res Treat 2015;2015:759589. doi: $10.1155 / \mathbf{2 0 1 5} / 759589$.

23. Gachkar L, Taremi M, Khoshbaten M. Frequency of antibodies to hepatitis E virus among male blood donors in Tabriz. Sci J Iran Blood Transfus Organ 2005;2:157-62.

24. Ghadir M, Jafar E, Rezvan H, Amini S, Vaez Javadi $\mathrm{M}$, pourshams A. Hepatitis A and E in East Province of Golestan. J Med Council of Iran 2007;25:34-8.

25. Ghorbani GA, Alavian SM, Esfahani AA. Seroepidemiology of Hepatitis E Virus in Iranian Soldiers. Hepat Mon 2007;7:123-6.

26. Joulaei H, Rudgari O, Motazedian N, Gorji-Makhsous S. Hepatitis E virus seroprevalence in HIV positive individuals in Shiraz,Southern Iran. Iran J Microbiol 2015;7:1038 .

27. Keramat F, Mamani M , Samadi M. Seroprevalence of Hepatitis E Virus Among Injection Drug Users and NonInjection Drug Users in Hamadan, West of Iran. Avicenna $J$ Clin Microb Infec 2014;1:22343. doi: 10.17795/ajcmi-22343

28. Khoshbaten M, Jafarinia N, Ansarin Kh, Fatemi R, Sharifian A, Khorram Z, et al. The prevalence of hepatitis A antibodies in hemodialysis patients in Tabriz in 2001. Pajoohandeh 2001;9:323-46.
29. Mobaien AR, Mohammadi R, Sorouri R, Sadeghi K. Hepatitis $\mathrm{E}$ virus seroprevalence in haemodialysis patients in Zanjan province, Islamic Republic of Iran. East Mediterr Health $J$ 2013;19:608-12.

30. Mohebbi SR, Rostami Nejad M, Tahaei SM, Pourhoseingholi MA, Habibi M, Azimzadeh P, et al. Seroepidemiology of hepatitis A and E virus infections in Tehran, Iran: a population based study. Trans $R$ Soc Trop Med Hyg 2012;106:528-31. doi: 10.1016/j.trstmh.2012.05.013.

31. Moradi A, Besharat S, Minaiifar M. Seroepidemiologic assessment of Hepatitis $\mathrm{E}$ virus in women of reproductive age, Gorgan. Zahedan J Res in Med Sci 2010;12:56-65.

32. Nazer MR, Raoofi R, Pournia Y. Seroepidemiology of hepatitis E virus in Western Iran. Braz J Infec Dis 2012;16:302-3. doi :10.1590/S1413-86702012000300017

33. Noroozi M, Moradi F, Hassanzadeh A, Banazadegan R, Basiri M, Ramezani A, et al. The prevalence in people over 15 years Hepatitis A and E in the province of Qom, 2011. Iran J Infec Dis Trop Med 2012;17:19-23.

34. Pourahmad M, Sotoodeh A R, Nasiri H. Hepatitis E Virus Infection in Hemodialysis Patients: A Seroepidemiological Survey in Jahrom, Southern Iran. Hepat Mon 2009;9:232-5

35. Ramezani A, Velayati AA, Khorami-Sarvestani S, Eslamifar A, Mohraz M, Banifazl M, et al. Hepatitis E virus infection in patients infected with human immunodeficiency virus in an endemic area in Iran. Int J STD AIDS 2013;24:769-74. doi: 10.1177/0956462413484457.

36. Rezazadeh M, Hajiloii M, Gachkar L, Yadegari D, Mani K, Naghdi M. Prevalence of antibodies against hepatitis A virus in patients in Hamedan Blood Transfusion Center in 2005. Iran J Infec Dis Trop Med 2006;11:13-8.

37. Rostamzadeh Khameneh Z, Sepehrvand N, Masudi S Seroprevalence of Hepatitis E among Iranian Renal Transplant Recipients. Hepat Mon 2011;11: 646-51. doi : 10.5812/kowsar.1735143X.690

38. Rostamzadeh Khameneh Z, Sepehrvand N, Khalkhali HR. Seroprevalence of Hepatitis E Among Pregnant Women in Urmia, Iran. Hepa Mon 2013;13:10931. doi: 10.5812/hepatmon.

39. SaffarM J, Farhadi R, Ajami A, Khalilian AR, Babamahmodi F, Saffar H. Seroepidemiology of hepatitis E virus infection in 2-25-year-olds in Sari district, Islamic Republic of Iran. La Revue de Sante de la Mediterranee orientale 2009;15:136-42.

40. Sepanlou S, Rezvan H, Amini-Kafiabad S, Dayhim MR, Merat S. A Population-based Seroepidemiological Study on Hepatitis E Virus in Iran. Midd East J Dig Dis 2010;2:97-103.

41. Zekavat OR, Makarem A, Karami MY, Amanat A, Mohandes M, Habibagahi M. Serological investigation for hepatitis $\mathrm{E}$ virus infection in the patients with chronic maintenance hemodialysis from southwest of Iran. Asian J Transfu Sci 2013;7: 21-5. doi: 10.4103/0973-6247.106724.

42. Shamsizadeh A, Nikfar R, Makvandi M, Shamsizadeh N. 
Seroprevalence of Hepatitis E Virus Infection in Children in the Southwest of Iran. Hepat Mon 2009;9: 261-4.

43. Sharif A, Sharif M, Taghavi A, Madani M, Khirkhah D, Afzali H. Seroepidemiology hepatitis E in children in Kashan in 2011. Iran J Infec Dis Trop Med 2013;18: 31-6.

44. Shavakhi A, Esteghamat F, Sharifian A, Mohamad Alizade AH, Khodadostan M, Somi MH, et al. Hepatitis E study in patients with cirrhosis of the liver, a case - control study. Govaresh 2007;12:27-9.

45. Somi MH, Farhang S, Majid G, Shavakhi A, Pouri AA. Seroprevalence of Hepatitis E in Patients with Chronic Liver Disease from East Azerbaijan, Iran. Hepat Mon 2007;7:127-30.

46. Tahamtan A, Moradi A, Ghaemi A, Kelishadi M, Ghafari $\mathrm{H}$, Hashemi P, et al. Seroepidemiology of Hepatitis E Virus in Hemodialysis Patients in Gorgan-Iran. Medi Labora J 2013;7:13-7.

47. Taremi M, Gachkar L, MahmoudArabi S, Kheradpezhouh M, Khoshbaten M. Prevalence of antibodies to hepatitis E virus among male blood donors in Tabriz, Islamic Republic of Iran. East Mediterr Health J 2007;13:98-102.

48. Taremi M, Khoshbaten M, Gachkar L, EhsaniArdakani M, Zali M. Hepatitis E virus infection in hemodialysis patients: A seroepidemiological survey in Iran. BMC Infec Dis 2005;5:36. doi: 10.1186/1471-2334-5-36

49. Taremi M, Mohammad Alizadeh AH, Ardalan A, Ansari S, Zali MR. Seroprevalence of hepatitis E in Nahavand, Islamic Republic of Iran: a population-based study. East Medit Health $J$ 2008;14:157-62.

50. Zekavat OR, Makarem A, Karami MY, Amanat A, Mohandes M, Habibagahi M. Serological investigation for hepatitis $\mathrm{E}$ virus infection in the patients with chronic maintenance hemodialysis from southwest of Iran. Asian J Transfu Sci 2013;7:21-5. doi: 10.4103/0973-6247.106724

51. Liberati A, Altman DG, Tetzlaff J, Mulrow C, Gøtzsche PC, Ioannidis JP, et al. The PRISMA Statement for Reporting Systematic Reviews and Meta-Analyses of Studies That Evaluate Health Care Interventions:Explanation and Elaboration. PLoS Med 2009;6: e1000100. doi :10.1371/ journal.pmed.1000100

52. Utba NM. The prevalence of hepatitis E virus in Al-Sadr City - Baghdad. Clin Lab 2013;59: 115-20. doi: 10.7754/ Clin.Lab.2012.120124

53. Al-Nasrawi KK, Al Diwan JK, Al-Hadithi TS, Saleh AM. Viral hepatitis E outbreak in Al-Sadr city, Baghdad, Iraq. East Mediterr Health J 2010;16: 1128-32.

54. Lankarani KB, Alavian SM, Peymani P. Health in the Islamic Republic of Iran, challenges and progresses. Med $J$ Islam Repub Iran 2013;27: 42-9. 